\title{
SCREENING AND CHARACTERIZATION OF A NOVEL ALKALINE LIPASE FROM ACINETOBACTER CALCOACETICUS 1-7 ISOLATED FROM BOHAI BAY IN CHINA FOR DETERGENT FORMULATION
}

\author{
Haikuan Wang; Shaojiong Zhong; Huijing Ma; Jie Zhang; Wei Qi*
}

Key Laboratory of Industrial Microbiology, Ministry of Education, College of Biotechnology, Tianjin University of Science and Technology, Tianjin 300457, China

Submitted: June 25, 2010; Returned to authors for corrections: December 15, 2011; Approved: January 16, 2012.

\begin{abstract}
A novel alkaline lipase-producing strain 1-7 identified as Acinetobacter calcoaceticus was isolated from soil samples collected from Bohai Bay, China, using an olive oil alkaline plate, which contained olive oil as the sole carbon source. The lipase from strain 1-7 showed the maximum activity at pH 9.0 under $40{ }^{\circ} \mathrm{C}$. One interesting feature of this enzyme is that it exhibits lipase activity over a broad range of temperatures and good stability. It is also stable at a broad range of pHs from 4.0 to 10.0 for $24 \mathrm{~h}$. Its catalytic activity was highly enhanced in the presence of $\mathrm{Ca}^{2+}, \mathrm{Mg}^{2+}$ and $\mathrm{K}^{+}$, but partially inhibited by $\mathrm{Cu}^{2+}, \mathrm{Al}^{3+}, \mathrm{Fe}^{3+}, \mathrm{Ba}^{2+}$ and $\mathrm{Zn}^{2+}$. The fact that it displays marked stability and activity in the presence of TritonX-100, Tween-20, Tween-80, SDS, Hydrogen peroxide, Sodium perborate, Sodium hypochlorite, Sodium citrate, Sodium taurocholate, Glycerine and $\mathrm{NaCl}$ suggests that this lipase is suitable as an additive in detergent formulations.
\end{abstract}

Key words: alkaline lipase; acinetobacter calcoaceticus; characterization; detergent.

\section{INTRODUCTION}

Lipases (triacylglycerol acylhydrolases; EC 3.1.1.3) are one of the most important classes of hydrolytic enzymes that catalyze both the hydrolysis and synthesis of esters $(9,10)$. The main reason for the steadily growing interest in lipases is because of their enantioselective, regioselective and chemoselective nature (28). Lipases occur widely in nature, but only microbial lipases are commercially significant, since they can be produced at low cost and exhibit improved stability (7).
The most commercially important field of application for hydrolytic lipases is their addition to detergents, which are used mainly in household and industrial laundry (8). Washing and degreasing by using lipases allows for smaller amounts of surfactants and operation at low temperatures (18). The lipase component causes an increase in detergency and prevents scaling, since enzymes can reduce the environmental load of detergent products (7). In 1994, Novo Nordisk introduced the first commercial lipase, Lipolase, which originated from the fungus T. lanuginosus and was expressed in A. oryzae. In 1995,

\footnotetext{
*Corresponding Author. Mailing address: Key Laboratory of Industrial Microbiology, Ministry of Education, College of Biotechnology, Tianjin University of Science and Technology, Tianjin 300457, China.; Tel.: 86-22-60601958; Fax: 86-22-60602298.; E-mail: haikuanwangcn@yahoo.com.cn
} 
two bacterial lipases were introduced-Lumafast from Pseudomonas mendocina and Lipomax from Pseudomonas alcaligenes, both produced by Genencor International, AUKBC Research Center, Life Sciences, Anna University, Chennai, India (7). Lipases used as detergents also include those from Candida (17) and Chromobacterium (15). Laundering is generally carried out in alkaline media, lipases active under such conditions are preferred, and for example, the $A$. oryzae derived lipase $(5,21,26)$. Alkaline Lipase produced by Acinetobacter radioresistens had an optimum $\mathrm{pH}$ of 10.0 and was stable over a $\mathrm{pH}$ range of 6.0-10.0; therefore have great potential for application in the detergent industry (3).

This study describes the production and characterization of a novel microbial lipase. We conducted an extensive screening of bacterial isolates collected from soils and isolated an alkaline lipase-producing strain 1-7, identified as Acinetobacter calcoaceticus. We provided experimental evidence that strain 1-7 produced a novel alkaline lipase capable of catalyzing the hydrolysis of esters at a broad range of temperatures and $\mathrm{pHs}$ in the presence of detergent ingredients.

\section{MATERIALS AND METHODS}

\section{Enrichment of Lipase-producing Microorganisms}

One gram of soil sample (collected from Bohai Bay, China) was added into a $250 \mathrm{~mL}$ Erlenmeyer flask containing $50 \mathrm{~mL}$ enriching medium with the composition $(\%)$ of yeast extract (Oxoid, England) 1, olive oil (Moreno, Spain) 2, $\mathrm{NaCl}$ $0.05, \mathrm{MgSO}_{4} \cdot 7 \mathrm{H}_{2} \mathrm{O}$ 0.02, $\mathrm{K}_{2} \mathrm{HPO}_{4}$ 0.1, peptone (Oxoid, England) 2, initial $\mathrm{pH}$ 8.0. The mixture was incubated at $37{ }^{\circ} \mathrm{C}$ on a rotary shaker (HYG II , Xinrui Co., China) at $180 \mathrm{rpm}$ for $72 \mathrm{~h}$.

\section{Isolation, Screening and Identification of Lipase-producing Microorganisms}

The grown microorganisms in the enrichment culture were isolated on the screening plates, which contain $(\%)$ $\mathrm{K}_{2} \mathrm{HPO}_{4} \quad 0.1, \mathrm{NaNO}_{3} \quad 0.3, \mathrm{MgSO}_{4} \bullet 7 \mathrm{H}_{2} \mathrm{O} \quad 0.05, \mathrm{FeSO}_{4} \bullet 7 \mathrm{H}_{2} \mathrm{O}$ 0.01, emulsion of olive oil (Moreno, Spain) (it contains $0.2 \%$ Victoria blue B (SCRC, China)) 2, agar (Solarbio, China) 2, initial $\mathrm{pH}$ 8.0. Plates were incubated at $37^{\circ} \mathrm{C}$ for $24 \mathrm{~h}$. First, the lipase activity was roughly estimated by Victoria Blue plate assay method (12). The growing colonies with blue zones were separately transferred to liquid medium, which contains (\%) soluble starch (Shuangxuan Co., China) 1, bean flour (Shuangxuan Co., China) 2, corn flour (Shuangxuan Co., China) $1,(\mathrm{NH} 4)_{2} \mathrm{SO}_{4} 0.5, \mathrm{~K}_{2} \mathrm{HPO}_{4} 0.1$, and emulsion of olive oil (Moreno, Spain) 2, initial $\mathrm{pH}$ 8.0. The mixture was incubated at $37{ }^{\circ} \mathrm{C}$ on a rotary shaker (HYG II , Xinrui Co., China) at $180 \mathrm{rpm}$ for $36 \mathrm{~h}$. After that $5 \mathrm{~mL}$ aliquot was performed at $60{ }^{\circ} \mathrm{C}$ for $30 \mathrm{~min}$, a second $5 \mathrm{~mL}$ aliquot was performed at $80{ }^{\circ} \mathrm{C}$ for $15 \mathrm{~min}$ and another $5 \mathrm{~mL}$ aliquot was performed at $100{ }^{\circ} \mathrm{C}$ for $10 \mathrm{~min}$, which were respectively added to 4-mm-diameter holes of the plates with $20 \mu \mathrm{L}$. Plates were incubated at $37{ }^{\circ} \mathrm{C}$ for $24 \mathrm{~h}$. Then, in order to select the best lipase producer for enzyme purification and characterization, strains with lipolytic activity on the plates were cultured in liquid medium, and lipase activity was determined with the spectrophotometric assay using p-NPP (Sigma, USA) as a substrate $(26,27,28)$.

Identification of strain 1-7 was conducted using $16 \mathrm{~S}$ ribosomal DNA (rDNA) analysis (4). The genomic DNA was extracted according to the method described by the instruction of the Genome DNA Extraction Kit (Biofuture, China). Two primers, F (5'- AGA GTT TGA TCC TGG CTC AG -3') and R (5'- CTA CGG CTA CCT TGT TAC GA -3'), were used for PCR (24). PCR amplification was carried out as follow: $94{ }^{\circ} \mathrm{C}$ for $1 \mathrm{~min}$; $94{ }^{\circ} \mathrm{C}$ for $45 \mathrm{~s}, 55^{\circ} \mathrm{C}$ for $45 \mathrm{~s}, 72{ }^{\circ} \mathrm{C}$ for $90 \mathrm{~s}, 30$ cycles; $72{ }^{\circ} \mathrm{C}$ for $10 \mathrm{~min}$. PCR was analyzed by Agarose Gel Electrophoresis and DNA was screened by gel documentation system (GeneGenius, Syngene, USA). The sequence analysis was performed by Sunnybio Corporation (Shanghai, China). A homology search to reference strains registered in DDBJ/ 
EMBL/ GenBank was performed using NCBI BLAST.

\section{Lipase Production}

Acinetobacter calcoaceticus 1-7 was grown in a liquid medium containing (\%) soluble starch (Shuangxuan Co., China) 1, bean flour (Shuangxuan Co., China) 2, corn flour (Shuangxuan Co., China) 1, (NH4) $)_{2} \mathrm{SO}_{4} 0.5, \mathrm{~K}_{2} \mathrm{HPO}_{4} 0.1$, and emulsion of olive oil (Moreno, Spain) 2, initial pH 9.0. Culture conditions were $37^{\circ} \mathrm{C}$ and $180 \mathrm{rpm}$ in a rotary shaker (HYG II , Xinrui Co., China), in the $250 \mathrm{~mL}$ flask containing $30 \mathrm{~mL}$ of medium. An aliquot of $0.6 \mathrm{~mL}$ of a $10 \mathrm{~h}$ pre-culture in the culture (containing (\%) peptone (Oxoid, England) 1, yeast extract (Oxoid, England) 0.5, $\mathrm{NaCl} 1$, initial $\mathrm{pH}$ 9.0.) was used as inoculum.

Crude enzyme was obtained by centrifugation (CR21G, Hitachi, Japan) at $10,000 \mathrm{rpm}$ at $4{ }^{\circ} \mathrm{C}$ for $10 \mathrm{~min}$. The cell-free supernatant was considered as crude enzyme (20).

\section{Lipase Activity}

Lipase activity was determined by the spectrophotometric method with p-nitrophenyl palmitate (p-NPP) (Sigma, USA) as the substrate. Solution A contained p-NPP (30 mg) dissolved in propane-2-ol $(10 \mathrm{~mL})$, solution B contained Triton X-100 (Biofuture, China) (1 mL) dissolved in $90 \mathrm{~mL}$ buffer $(0.1$ $\mathrm{mol} / \mathrm{L}$ Gly-NaOH, $\mathrm{pH}$ 9.0). The assay solution was prepared by adding solution A to solution $\mathrm{B}$. The assay mixture contained $900 \mu \mathrm{L}$ of the emulsion and $100 \mu \mathrm{L}$ of the appropriately diluted lipase (boiled for 30 minutes as blanks) solution. The reaction was performed at $40{ }^{\circ} \mathrm{C}$ for $15 \mathrm{~min}$ and terminated at $4{ }^{\circ} \mathrm{C}$ for $10 \mathrm{~min}$. The liberated p-nitrophenol was measured at $410 \mathrm{~nm}$ by spectrophotometer (TU-1810, Pgeneral Co., China). One unit $(\mathrm{U} / \mathrm{mL})$ of lipase was defined as the amount of lipase that releases $1 \mathrm{mmol}$ p-nitrophenol per minute at $40{ }^{\circ} \mathrm{C}, \mathrm{pH} 9.0$ (26).

\section{Properties of Lipase}

The optimal temperature of the lipase was evaluated by using the lipase activity assay with p-NPP (Sigma, USA) at various temperatures from $20{ }^{\circ} \mathrm{C}$ to $50{ }^{\circ} \mathrm{C}$ under $\mathrm{pH}$ 8.0. The stability of the lipase was determined by measuring the residual activity after $60 \mathrm{~h}$ of pre-incubation in sodium phosphate buffer (pH 8.0) at various temperatures.

The optimal $\mathrm{pH}$ of the lipase was measured by incubating the lipase substrate at various $\mathrm{pHs}$ from 3.0 to 10.0. The following buffers $(0.1 \mathrm{~mol} / \mathrm{L})$ were sodium acetate buffer $(\mathrm{pH}$ 3.0-5.0), sodium phosphate buffer ( $\mathrm{pH} 6.0-8.0$ ), and Gly- $\mathrm{NaOH}$ buffer ( $\mathrm{pH}$ 9.0-10.0), and were adjusted to the optimal enzyme reaction temperature.

To determine the effect of metal ions on lipase activity, the enzyme solution was pre-incubated with metal ions (1 mmol/L) such as $\mathrm{ZnCl}_{2}, \mathrm{CuCl}_{2}, \mathrm{MnCl}_{2}, \mathrm{AlCl}_{3}, \mathrm{KCl}, \mathrm{FeCl}_{2}$, $\mathrm{FeCl}_{3}, \mathrm{BaCl}_{2}, \mathrm{MgCl}_{2}$ and $\mathrm{CaCl}_{2}$ at $40{ }^{\circ} \mathrm{C}$ for $20 \mathrm{~min}$ and then the residual activity was determined.

In order to determine the potential application of lipase from Acinetobacter calcoaceticus 1-7 in detergent industry, its compatibility with various surfactants and oxidizing agents was investigated by respectively adding TritonX-100, Tween-20, Tween-80, SDS, Hydrogen peroxide, Sodium perborate, Sodium hypochlorite, Sodium citrate, Sodium taurocholate, Glycerine and $\mathrm{NaCl}$ into the activity assay mixture, then the lipase samples were incubated for $1 \mathrm{~h}$ at $40{ }^{\circ} \mathrm{C}$ and their activity was determined by the spectrophotometric assay at $\mathrm{pH}$ 9.0 and $40{ }^{\circ} \mathrm{C}$. The residual lipase activity in each sample was determined.

\section{RESULTS AND DISCUSSION}

\section{Screening and Identification of Lipase-producing Microorganisms}

Fifty six strains with high lipase activity from 189 samples were isolated by enrichment cultures, among which 6 strains were shown to produce alkaline lipases. Strain 1-7 was selected for subsequent experiments due to its ability to produce a lipase with good stability at various temperatures 
(Table 1). The taxonomic identification of the strain 1-7 was showed $99 \%$ homology to Acinetobacter calcoaceticus conducted. The sequence of $16 \mathrm{~S}$ rDNA of the strain 1-7 compared with the GenBank database.

Table 1. The size of rings formed on Victoria Blue agar plate with the crude lipases of six strains

\begin{tabular}{ccccc}
\hline Strains & \multicolumn{4}{c}{ Diameter of the blue zones (mm) } \\
\cline { 2 - 4 } $1-7$ & Control & $\mathrm{A}$ & $\mathrm{B}$ & $\mathrm{C}$ \\
$2-12$ & 10.0 & 8.5 & 7.0 & 5.0 \\
$3-1$ & 7.0 & 6.0 & 5.0 & 4.5 \\
$3-2$ & 9.0 & 7.5 & 6.0 & 4.5 \\
$3-5$ & 8.0 & 6.5 & 5.5 & 4.5 \\
$3-19$ & 8.5 & 7.0 & 5.5 & 4.5 \\
& 10.0 & 8.0 & 6.0 & 4.5 \\
\hline
\end{tabular}

(A) The lipase incubation at $60{ }^{\circ} \mathrm{C}$ for $30 \mathrm{~min}, \mathrm{pH}$ 8.0. (B) The lipase incubation at $80{ }^{\circ} \mathrm{C}$ for $15 \mathrm{~min}, \mathrm{pH} 8.0$. (C) The lipase incubation at $100^{\circ} \mathrm{C}$ for $10 \mathrm{~min}, \mathrm{pH} 8.0$.

\section{Effects of Temperature on Lipase Activity}

The lipase exhibited optimum lipolytic activity at $40{ }^{\circ} \mathrm{C}$ and has substantial activity from $20{ }^{\circ} \mathrm{C}$ to $50{ }^{\circ} \mathrm{C}$ with the relative activity of $87 \%$ at $20{ }^{\circ} \mathrm{C}, 96 \%$ at $30{ }^{\circ} \mathrm{C}, 100 \%$ at 40 ${ }^{\circ} \mathrm{C}$ and $85 \%$ at $50{ }^{\circ} \mathrm{C}$. However, at low temperature $\left(5{ }^{\circ} \mathrm{C}\right)$ and high temperature $\left(70{ }^{\circ} \mathrm{C}\right)$, the lipase activity was greatly reduced (Figure 1). And as shown in Figure 2, stability test at various temperatures for $60 \mathrm{~h}$ at $\mathrm{pH} 8.0$ showed that the enzyme was relatively stable, since it retained almost $90 \%$ of its activity at $20^{\circ} \mathrm{C}$ to $50{ }^{\circ} \mathrm{C}$.

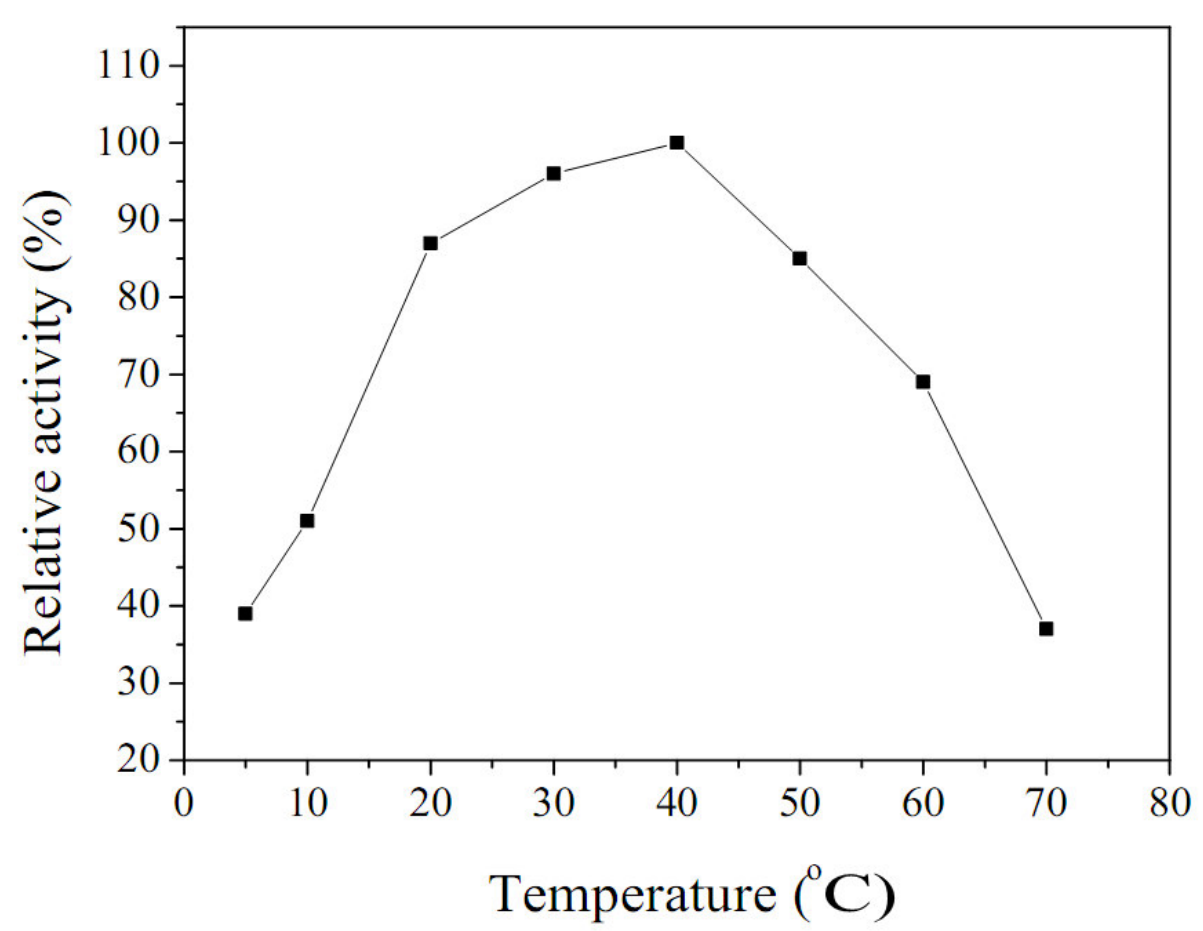

Figure 1. Effects of temperature on the activity of the lipase. The lipase reaction was incubated for 15 min at various temperatures, $\mathrm{pH} 8.0$. 


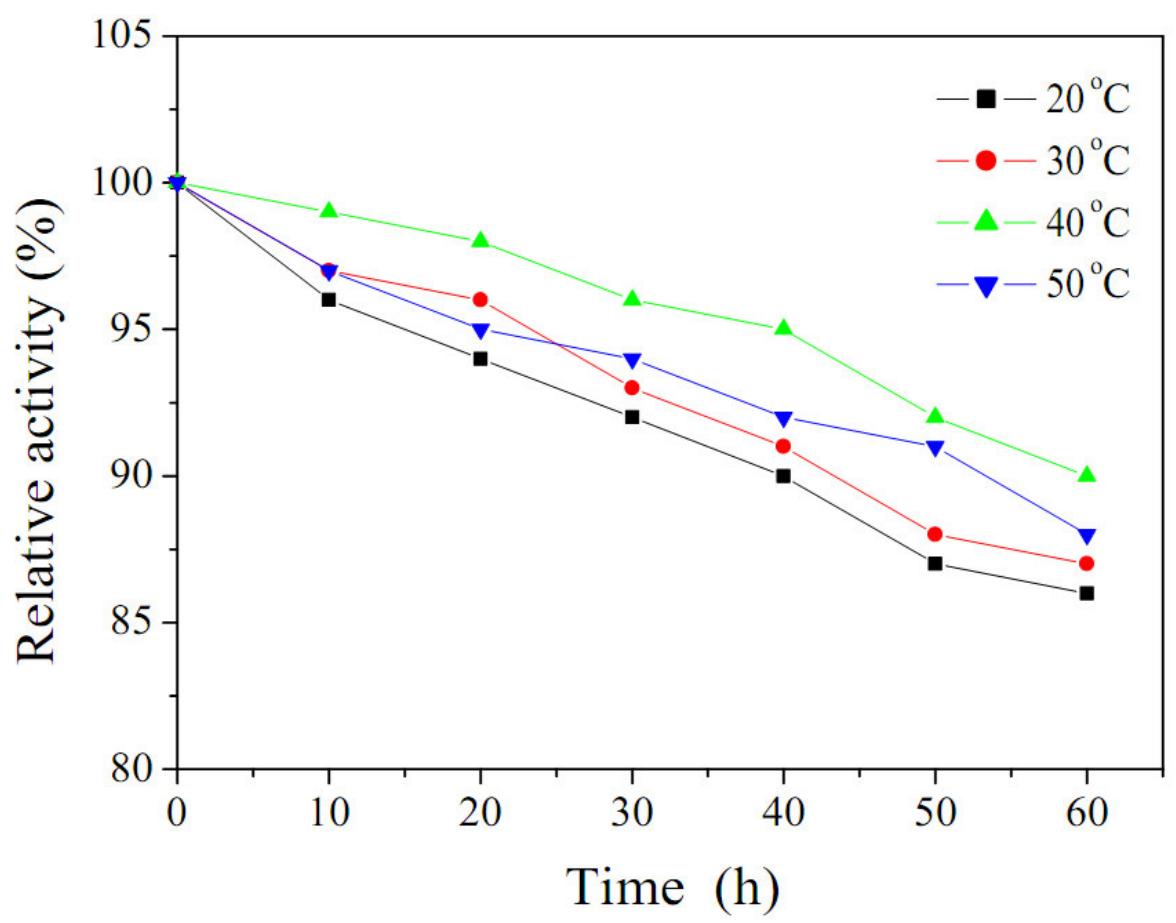

Figure 2. The stability of lipase from Acinetobacter calcoaceticus $1-7$ was measured at $20{ }^{\circ} \mathrm{C}-50{ }^{\circ} \mathrm{C}$. The relative activity was assayed after incubation at indicated temperatures for $60 \mathrm{~h}$ with the interval of $10 \mathrm{~h}$.

\section{Effects of pH on Lipase Activity}

The optimum activity of the lipase was observed at $\mathrm{pH}$ 9.0, consistent with the results based on the plate method. The lipase was also highly active over a wide $\mathrm{pH}$ range (4.0-10.0) (Figure 3). It retained $80 \%$ of its activity at $\mathrm{pH} 5.0,86 \%$ at $\mathrm{pH}$ 6.0, $92 \%$ at $\mathrm{pH} 7.0,96 \%$ at $\mathrm{pH} 8.0,100 \%$ at $\mathrm{pH} 9.0$ and $90 \%$ at $\mathrm{pH} 10.0$ after $24 \mathrm{~h}$ at $40{ }^{\circ} \mathrm{C}$. It is noteworthy that the lipase retained $56 \%$ activity even at $\mathrm{pH}$ 3.0. And as shown in Figure 4 , stability test at various $\mathrm{pHs}$ for $24 \mathrm{~h}$ at $40{ }^{\circ} \mathrm{C}$ shown that the lipase was relatively active over a wide $\mathrm{pH}$ range. The remarkable wide $\mathrm{pH}$ range of the Acinetobacter calcoaceticus lipase justifies its further investigation for commercial applications.

As has been reported for other lipases, the enzyme from Bacillus sp. RSJ-1 showed good stability as it retained $>90 \%$ activity at $60{ }^{\circ} \mathrm{C}$ for $1 \mathrm{~h}$ under alkaline conditions and also exhibited a half life of $>150 \mathrm{~min}$ at $60{ }^{\circ} \mathrm{C}$ and $45 \mathrm{~min}$ at $70{ }^{\circ} \mathrm{C}$, respectively. The enzyme exhibited the good stability in an alkaline $\mathrm{pH}$ range, as it retained $>95 \%$ activity at $\mathrm{pH} 9.0$, which reduced to $78 \%$ at $\mathrm{pH} 10.0$ after $1 \mathrm{~h}$ of incubation (23). The results showed the lipase from Pseudomonas aeruginosa SRT 9 that exhibited fairly stable activity ranging from 55 to $65^{\circ} \mathrm{C}$, and the enzyme was remarkably stable in the $\mathrm{pH}$ rang 6.0 to 7.5 retaining $68 \%$ of the residual activity at $\mathrm{pH} 8.0$ (2). The lipase from Geobacillus thermoleovorans was stable at temperature range $40{ }^{\circ} \mathrm{C}$ to $60{ }^{\circ} \mathrm{C}$ with no loss of activity, whereas increasing incubation temperature up to $100{ }^{\circ} \mathrm{C}$ led to $70 \%$ loss of activity after 60 min of incubation. However, its activity of lipase was only observed at pH 7.0-8.0 (1). Actually, preferred lipases for detergent components are those which show sufficient lipase activity in washing solutions and washing conditions. Generally the $\mathrm{pH}$ of washing solutions is in the alkaline region. in some countries such as Japan, the temperature of washing water is $40{ }^{\circ} \mathrm{C}(25)$. Therefore, the stability of Acinetobacter calcoaceticus lipase in alkaline $\mathrm{pH}$ and at various temperatures suggests its potential utility in industrial applications. 


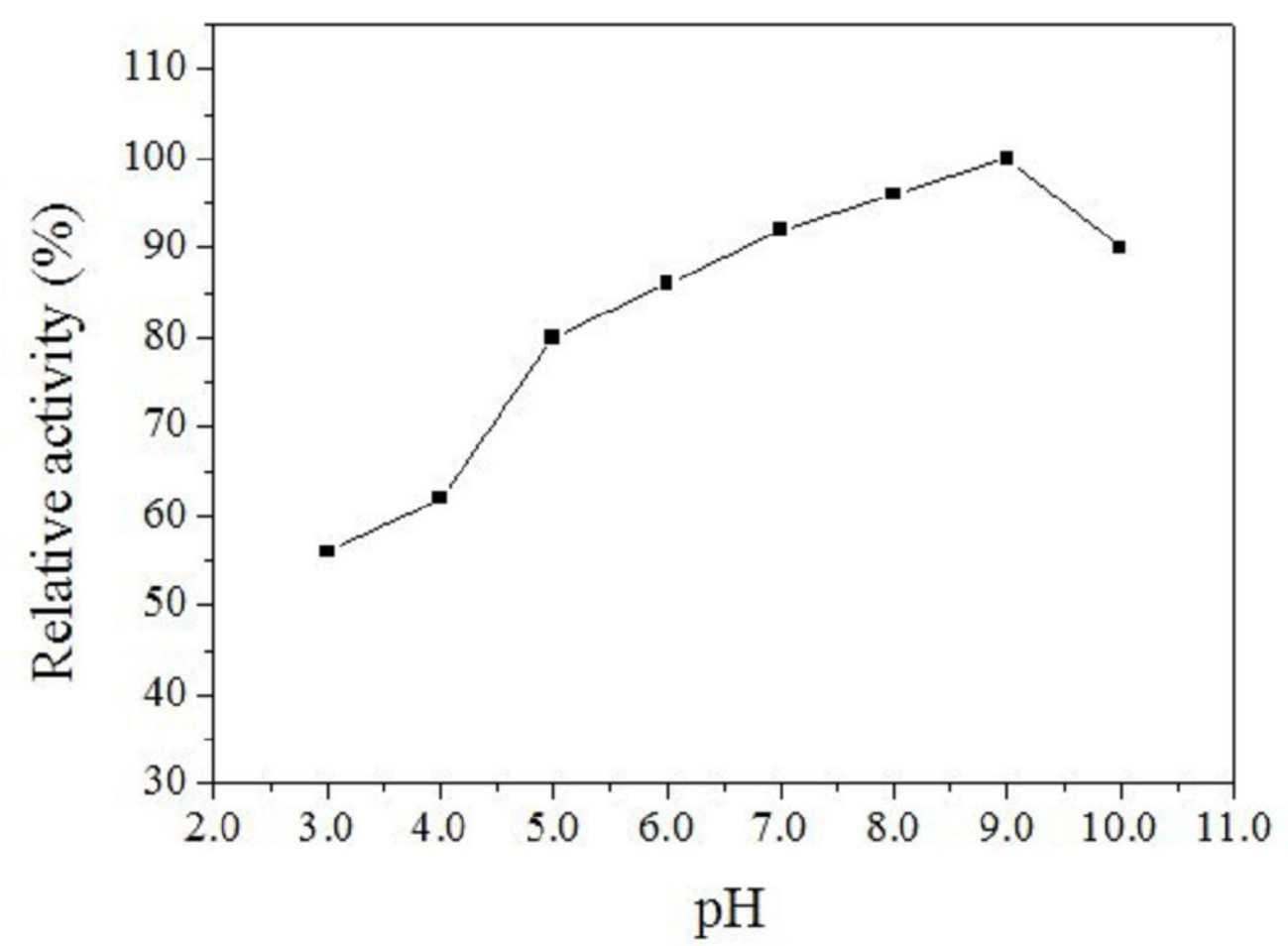

Figure 3. Effects of $\mathrm{pH}$ on the activity of the lipase. The reaction was determined at $40{ }^{\circ} \mathrm{C}$ under different buffers $(0.1 \mathrm{~mol} / \mathrm{L})$ at various pHs from 3.0 to 10.0, sodium acetate buffer ( $\mathrm{pH} 3.0-5.0$ ), sodium phosphate buffer ( $\mathrm{pH}$ 6.0-8.0), and Gly-NaOH buffer (pH 9.0-10.0).

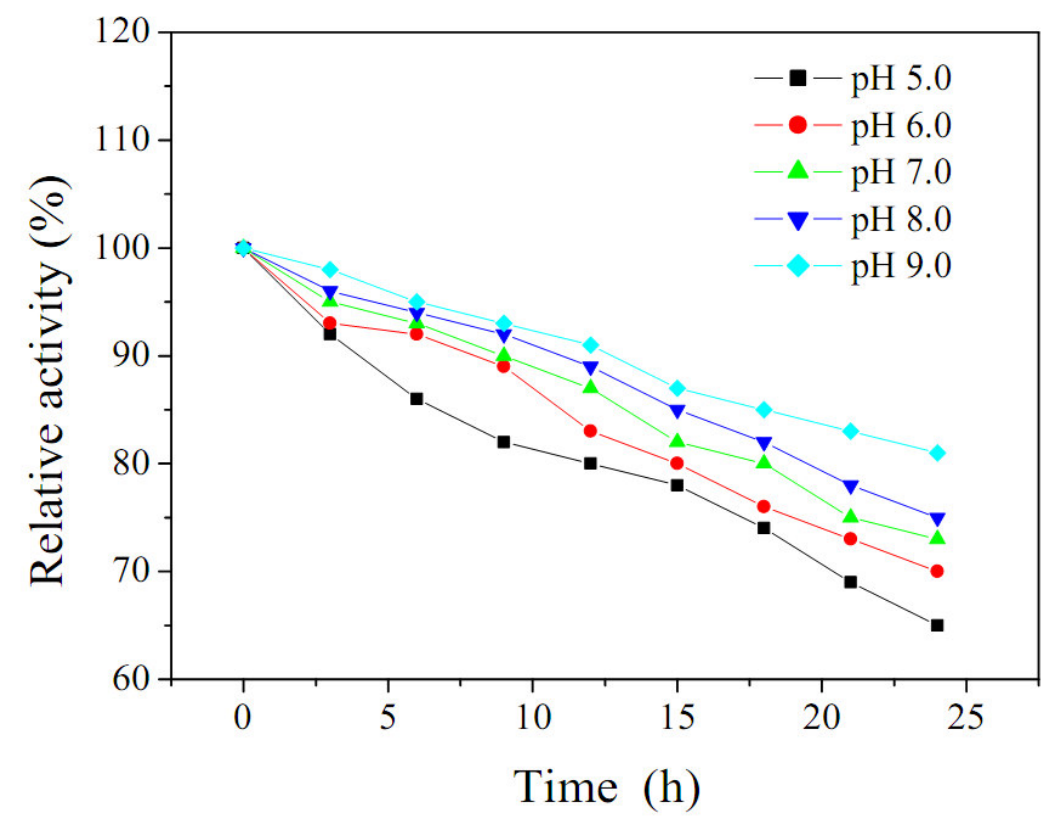

Figure 4. The stability of lipase from Acinetobacter calcoaceticus 1-7 was measured at pH 5.0-9.0. The lipase was incubated for $24 \mathrm{~h}$ at $40{ }^{\circ} \mathrm{C}$ in various buffers $(0.1 \mathrm{~mol} / \mathrm{L})$, sodium acetate buffer ( $\left.\mathrm{pH} 3.0-5.0\right)$, sodium phosphate buffer (pH 6.0-8.0), and Gly$\mathrm{NaOH}$ buffer ( $\mathrm{pH}$ 9.0-10.0). The residual activity was measured with the spectrophotometric assay using p-NPP as a substrate. 


\section{Effects of Metal ions on Lipase Activity}

Effects of different metal ions on the activity of the lipase were shown in Table 2. $\mathrm{K}^{+}, \mathrm{Ca}^{2+}$, and $\mathrm{Mg}^{2+}$ were found to enhance the lipase activity. While $\mathrm{Al}^{3+}, \mathrm{Fe}^{3+}, \mathrm{Ba}^{2+}$ and $\mathrm{Zn}^{2+}$ partially inhibited the enzymatic activity, $\mathrm{Cu}^{2+}$ completely inhibited the lipase activity. Lipase activity was not affected by the presence of $\mathrm{Fe}^{2+}$ and $\mathrm{Mn}^{2+}$.

As has been reported for other lipases, $\mathrm{Ca}^{2+}$ salts increased activity immediately (59\%) and after $1 \mathrm{~h}$ of incubation at 30 ${ }^{\circ} \mathrm{C}(35 \%)(6,13,14)$. The calcium-induced increase on lipase activity could be attributed to the complex action of calcium ions on the released fatty acids, and on enzyme structure stabilization due to the binding of calcium ions to the lipase, bridging the active region to a second subdomain of the protein and hence stabilizing enzyme tertiary structure (11). Another reported that $\mathrm{Ca}^{2+}$ showed stimulatory effect whereas $\mathrm{Mg}^{2+}$, $\mathrm{Mn}^{2+}, \mathrm{Ba}^{2+}$ had negligible effect on the enzyme activity. However, $\mathrm{Fe}^{2+}, \mathrm{Cu}^{2+}$ and $\mathrm{Zn}^{2+}$ reduced enzyme activity to less than $37 \%$ of its relative activity (2).

Table 2. Lipase stability in presence of metal ions

\begin{tabular}{cccc}
\hline Metal ions (1 mmol/L) & Relative activity (\%) & Metal ions (1 mmol/L) & Relative activity (\%) \\
\hline $\mathrm{Zn}^{2+}$ & 47 & $\mathrm{Fe}^{2+}$ & 93 \\
$\mathrm{Cu}^{2+}$ & 0 & $\mathrm{Fe}^{3+}$ & 51 \\
$\mathrm{Al}^{3+}$ & 39 & $\mathrm{Ba}^{2+}$ & 69 \\
$\mathrm{Mn}^{2+}$ & 90 & $\mathrm{Ca}^{2+}$ & 141 \\
$\mathrm{~K}^{+}$ & 112 & $\mathrm{Mg}^{2+}$ & 126 \\
\hline
\end{tabular}

\section{Effects of Surfactants, Oxidizing Agents and Detergent}

\section{Ingredients on Lipase Activity}

Besides $\mathrm{pH}$ and temperature stability, a good detergent lipase should also be stable in the presence of various surfactants. The effects of various surfactants, oxidizing agents and detergent ingredients on lipase activity are depicted in Table 3. Addition of $1 \%$ Triton X-100 to the lipase mixture increased the enzyme activity, but $10 \%$ Triton X-100 inhibited its activity, while it was completely inhibited in the presence of $1 \%$ and $10 \%$ SDS, Tween-80 and Tween-20, the effects was apparent under increased concentrations. However, addition of $0.1 \%$ and $1 \%$ Sodium cholate and Sodium taurocholate were found to enhance the enzyme activity apparently. Glycerine, $\mathrm{NaCl}$ and Sodium citrate were also found to highly enhance the enzyme activity. All of the oxidizing agents shown in Table 3 had little effect on the lipase activity.
As has been reported for other lipases, Schmidt-Dannert et al. (22) reported a total loss of lipolytic activity in the presence of Tween-20 and Tween-80, but no effect was observed when was incubated with Triton X-100. Prazeres et al. (19) observed Tween-40, Tween-80 and surfactin inhibited up to $30 \%$ lipase activity, but Triton X-100 and Triton X-114 showed an activating effect. Nawani et al. (16) found a total loss of activity in the presence of SDS. In contrast, activity was enhanced in the presence of TritonX-100, Tween-20 and Tween-80. Hydrogen peroxide, Sodium perborate and Sodium hypochlorite had little effect on the enzyme activity. Sodium cholate, Sodium taurocholate, Glycerine and $\mathrm{NaCl}$ were found to enhance the enzyme activity. Thus, the lipase from Acinetobacter calcoaceticus 1-7 suggested a good potential application in the detergent industry. 
Table 3. Lipase stability in presence of surfactants, detergents and oxidizing agents

\begin{tabular}{ccc}
\hline & Treatments & Relative activity (\%) \\
\hline Control & & 100 \\
& $1 \%$ TritonX-100 & 108 \\
& $10 \%$ TritonX-100 & 52 \\
& $1 \%$ Tween-20 & 51.6 \\
& $10 \%$ Tween-20 & 16.3 \\
& $1 \%$ Tween-80 & 61.2 \\
& $10 \%$ Tween-80 & 17.9 \\
& $1 \%$ SDS & 23.7 \\
& $10 \%$ SDS & 10.2 \\
& $1 \%$ Sodium cholate & 131.5 \\
& $0.1 \%$ Sodium cholate & 125.2 \\
$1 \%$ Sodium taurocholate & 177.9 \\
$0.1 \%$ Sodium taurocholate & 138.3 \\
$4 \%$ Glycerine & 209 \\
& $0.4 \%$ Glycerine & 281 \\
& $4 \%$ NaCl & 266 \\
& $0.4 \%$ NaCl & 244 \\
Oxidizing agents & $2 \%$ sodium citrate & 116 \\
& $0.2 \%$ sodium citrate & 167 \\
& $1 \%$ Hydrogen peroxide & 91 \\
$0.1 \%$ Hydrogen peroxide & 93 \\
$1 \%$ Sodium perborate & 95 \\
$0.1 \%$ Sodium perborate & 96 \\
$1 \%$ Sodium hypochlorite & 92 \\
$0.1 \%$ Sodium hypochlorite & 95 \\
\hline
\end{tabular}

\section{CONCLUSION}

In aqueous solution, the lipase of Acinetobacter calcoaceticus 1-7 shows some interesting properties such as stability at a broad range of pHs (4.0-10.0) with the optimum activity at $\mathrm{pH}$ 9.0. It also showed good stability ranging from $20{ }^{\circ} \mathrm{C}$ to $50{ }^{\circ} \mathrm{C}$ with the maximum activity at $40{ }^{\circ} \mathrm{C}$. Our experimental evidence clearly indicated that the lipase produced by the strain 1-7 is a moderate thermophilic alkaline lipase. Its activity was highly enhanced at the presence of $\mathrm{Ca}^{2+}$, $\mathrm{Mg}^{2+}$ and $\mathrm{K}^{+}$. In contrast, it was almost completely inhibited by $\mathrm{Cu}^{2+}$, while $\mathrm{Al}^{3+}, \mathrm{Fe}^{3+}, \mathrm{Ba}^{2+}$ and $\mathrm{Zn}^{2+}$ partially inhibited the enzymatic activity. Moreover, it was resistant to various surfactants, oxidizing agents and enzyme inhibitors, such as Tween-20, Tween-80, Triton X-100, and SDS, while Sodium cholate, Sodium taurocholate, Glycerine, $\mathrm{NaCl}$, Sodium citrate enhance its enzymatic activity. The present studies showed that this novel lipase has the potential for applications in the detergent industry.

\section{ACKNOWLEDGEMENTS}

This work was supported by Tianjin Natural Science Foundation (No. 09JCZDJC17800 and No. 07JCYBJC07900).

\section{REFERENCES}

1. Abdel-Fattah, Y.R.; Gaballa, A.A. (2008). Identification and overexpression of a thermostable lipase from Geobacillus thermoleovorans Toshki in Escherichia coli. Microbiol. Res. 163 (1), 13-20.

2. Borkar, P.S.; Bodade, R.G.; Rao,S.R.; Khobragade, C.N. (2009). Purification and characterization of extracellular lipase from a new strain - Pseudomonas aeruginosa SRT 9. Braz. J. Microbiol. 40 (2), 358-366.

3. Chen, S.J.; Cheng, C.Y.; Chen, T.L. (1998). Production of an alkaline lipase by Acinetobacter radioresistens. J. Ferment. Bioeng. 86 (3), 308312 .

4. Eltaweel, M.A.; Rahman, R.A.; Salleh, A.B.; Basri, M. (2005) An organic solvent-stable lipase from Bacillus sp. strain 42. Ann. Microbiol. 55 (3), 187-192. 
Gerhartz, W. (1990). Enzymes in industry: Production and Application. VCH Press, Weinheim.

5. Handelsman, T.; Shoham, Y. (1994). Production and characterization of an extracellular thermostable lipase from a thermophilic Bacillus sp. $J$. Gen. Appl. Microbiol. 40 (5), 435-443.

6. Hasan, F.; Shah, A.A.; Hameed, A. (2006). Industrial applications of microbial lipases. Enz. Microb Technol. 39 (2), 235-251.

7. Ito, S.; Kobayashi, T.; Ara, K.; Ozaki, K.; Kawai, S.; Hatada, Y. (1998). Alkaline detergent enzymes from alkaliphiles: enzymatic properties, genetics, and structures. Extremophiles. 2 (3), 185-190.

8. Jaeger, K.E.; Dijkstra, B.W.; Reetz, M.T. (1999). BACTERIAL BIOCATALYSTS: Molecular Biology, Three-Dimensional Structures, and Biotechnological Applications of Lipases. Annu. Rev. Microbiology. 53 (1), 315-351.

9. Jaeger, K.E.; Reetz, M.T. (1998). Microbial lipases form versatile tools for biotechnology. Trends. Biotechnol. 16 (9), 396-403.

10. Kim, M.H.; Kim, H.K.; Lee, J.K.; Park, S.Y.; Oh, T.K. (2000). Thermostable lipase of Bacillus stearothermophilus: high level production, purification, and calcium-dependent thermostability. Biosci. Biotechnol. Biochem. 64 (2), 280-286.

11. Kouker, G.; Jaeger, K.E. (1987). Specific and sensitive plate assay for bacterial lipases. Appl. Environ. Microb. 53 (1), 211-213.

12. Lee, D.W.; Kim, H.W.; Lee, K.W.; Kim, B.C.; Choe, E.A.; Lee, H.S.; Kim, D.S.; Pyun, Y.R. (2001). Purification and characterization of two distinct thermostable lipases from the gram-positive thermophilic bacterium Bacillus thermoleovorans ID-1. Enz. Microb. Technol. 29 (67), 363-371

13. Lee, D.W.; Koh, Y.S.; Kim, K.; Kim, B.; Choi, H.; Kim, D.; Suhartono, M.T.; Pyun, Y. (1999). Isolation and characterization of a thermophilic lipase from Bacillus thermoleovorans ID-1. FEMS. Microbiol. Lett. 179 (2), 393-400.

14. Minoguchi, M.; Mukaiyama, T. November 1989. Immobilization of lipase on polyacrylamide and its use in detergents. J.P. Pat. 1, 285, 188.

15. Nawani, N.; Dosanjh, N.S.; Kaur, J. (1998). A novel thermostable lipase from a thermophilic Bacillus sp.: characterization and esterification studies. Biotechnol. Lett. 20 (10), 997-1000.
16. Nishioka, M.; Takama, M. April 1990. Lipase manufacture with Candida for use in detergents. J.P. Pat 292, 281.

17. Novak, J.; Kralova, B.; Demnerova, K.; Prochazka, K.; Vodrazka, Z.; Tolman, J.; Rysova, D.; Smidrkal, J.; Lopata, V. February 1990. Enzyme agent based on lipases and oxidoreductases for washing, degreasing and water reconditioning. E.U. Pat. 355, 228.

19 Prazeres, J.N.; Cruz, J.A.B.; Pastore, G.M. (2006). Characterization of alkaline lipase from Fusarium oxysporum and the effect of different surfactants and detergents on the enzyme activity. Braz. J. Microbiol.37 (4), 505-509.

20. Sangeetha, R.; Geetha, A.; Arulpandi, I. (2010). Concomitant production of protease and lipase by Bacillus Licheniformis VSG 1: Production, purification and characterization. Braz. J. Microbiol. 41 (1), 179-185.

21. Satsuki, T.; Watanabe, T. (1990). Application of lipase to laundry detergents. Bio. Ind. 7, 501-507.

22. Schmidt-Dannert, C.; Sztajer, H.; Stocklein, W.; Menge, U.; Schmid, R.D. (1994). Screening, purification and properties of a thermophilic lipase from Bacillus thermocatenulatus. Biochim. Biophys. Acta. 1214 (1), 43-53.

23. Sharma, R.; Soni, S.K.; Vohra, R.M.; Gupta, L.K.; Gupta, J.K. (2002). Purification and characterization of a thermostable alkaline lipase from a new thermophilic Bacillus sp. RSJ-1. Process. Biochem. 37 (10), 10751084.

24. Sun, T.S.; Zhao, S.P.; Wang, H.K.; Cai, C.K.; Chen, Y.F.; Zhang, H.P. (2009) ACE-inhibitory activity and gamma-aminobutyric acid content of fermented skim milk by Lactobacillus helveticus isolated from Xinjiang koumiss in China. Eur. Food Res. Technol. 228 (4), 607-612.

25. Suzuki, M. October 2001. Alkaline lipase and detergent composition active at low temperature. U.S. Pat. 6, 306, 813.

26. Umehara, K.; Masago, Y.; Mukaiyama, T.; Okumura, O. (1990). Behavior of alkaline lipase on detergency. Yukagaku. 39, 322-326.

27. Vorderwülbecke, T.; Kieslich, K.; Erdmann, H. (1992). Comparison of lipases by different assays. Enz. Microb. Technol. 14 (8), 631-639.

28. Winkler, U.K.; Stuckmann, M. (1979). Glycogen, hyaluronate, and some other polysaccharides greatly enhance the formation of exolipase by Serratia marcescens. J. Bacteriol. 138 (3), 663-670. 